\title{
PEMBUATAN NANOPARTIKEL ALBUMIN MENGGUNAKAN METODE DESOLVASI SEBAGAI ALTERNATIF SISTEM PEMBAWA
}

\author{
Rini Ambarwati \\ Program Studi Farmasi, Fakultas MIPA, Universitas Pakuan, Bogor \\ Email: riniambarwati2507@gmail.com
}

\begin{abstract}
ABSTRAK
Desolvasi merupakan teknik pembuatan nanopartikel berdasarkan perbedaan kelarutan antara desolvating agent dengan pelarut air yang bercampur BSA. Tujuan dari penelitian ini adalah mengembangkan teknik desolvasi untuk pembuatan nanopartikel. berbahan Bovine Serum Albumen (BSA) dengan metode desolvasi. Parameter yang diuji adalah optimasi penggunaan beberapa macam bahan desolvating agent, jumlah BSA, jumlah desolvating agent, lama waktu pengadukan, dan $\mathrm{pH}$ dari pelarut. Nanopartikel BSA. Hasil yang didapat menunjukkan bahwa nanopartikel BSA terbaik adalah nanopartikel BSA yang menggunakan $4 \mathrm{~mL}$ aseton sebagai desolvating agent dan $30 \mathrm{mg}$ BSA $30 \mathrm{mg}$ dalam $2 \mathrm{~mL}$ pelarut air, dengan waktu pengadukan selama 3 jam dan $\mathrm{pH} 9$.

Kata kunci: Nanopartikel, BSA, Desolvasi, Albumin, Desolvating agent

\section{NANOPARTICLE ALBUMIN PRODUCTION USING DESOLVATION METHOD AS AN ALTERNATIVE CAREER SYSTEM ABSTRACT}

Desolvation is a technique of making nanoparticles based on differences in solubility between desolvating agents and BSA-mixed water solvents. The purpose of this study was to develop desolvation techniques for the manufacture of nanoparticles. BSA-based nanoparticles, by optimizing the use of several types of desolvating agent materials, the amount of BSA, the amount of desolvating agent, the time of stirring, and the $\mathrm{pH}$ of the solvent. The method of making nanoparticles in this study was carried out by the desolvation method, and albumin used was Bovine Serum Albumin (BSA). BSA nanoparticles formed were using acetone as desolvating agent, BSA amount of $30 \mathrm{mg}$ in $2 \mathrm{~mL}$ of water solvent, amount of desolvating agent added $4 \mathrm{~mL}$, stirring time for 3 hours, and $\mathrm{pH} 9$.
\end{abstract}

Keywords: Nanoparticle, BSA, Desolvation, Albumin, Desolvating agent

\section{PENDAHULUAN}

Albumin dipilih sebagai bahan utama dari sistem pembawa nanopartikel karena dapat berpenetrasi dan terakumulasi dalam tumor disebabkan albumin yang memiliki afinitas terhadap kanker (Elzoghby et al., 2011). Jaringan kanker memiliki permeabilitas pembuluh darah yang lebih tinggi dari pada jaringan normal, disebut efek enhanced permeability and retention (EPR). Partikel dengan diameter $<200 \mathrm{~nm}$ dapat secara pasif mengenali jaringan tumor sehingga efek EPR ini meningkatkan selektifitas nanopartikel. Sel kanker menggunakan albumin sebagai sumber asam amino. Akibatnya, nanopartikel albumin akan diambil dan mengalami degradasi. Sehingga, diharapkan dari penelitian ini dapat dikembangkan sistem pembawa yang dapat berpenetrasi ke dalam sel kanker dalam bentuk dan ukuran nanometer. Mekanisme pengambilan albumin melibatkan reseptor spesifik albumin yaitu protein gp60 yang merupakan reseptor albumin pada endotel pembuluh darah jaringan kanker yang diduga terlibat 
dalam proses endositosis albumin ke dalam sel kanker (Yuan, et al., 2013).

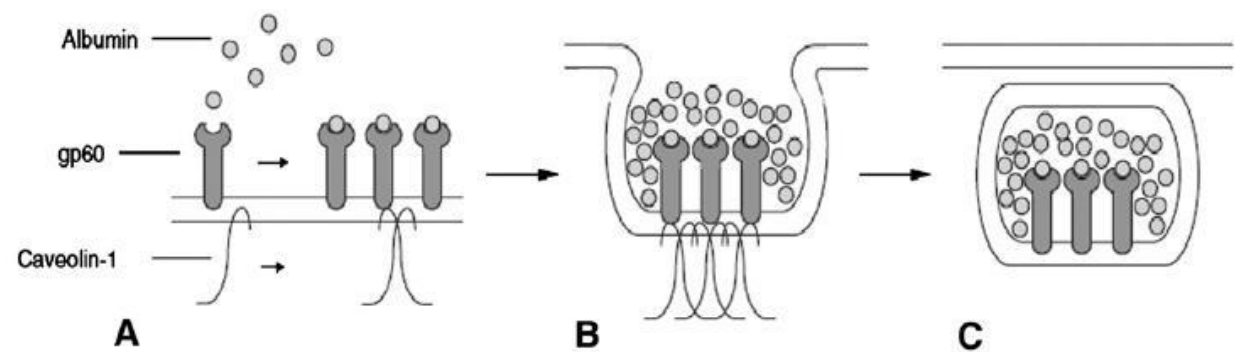

Gambar I. Mekanisme masuknya Albumin nanopartikel ke dalam sel kanker. (A) Reseptor albumin gp60 mengikat albumin, (B) sehingga menginduksi membran untuk membentuk Caveola, (C) caveola terbentuk dan selanjutnya mengalami proses transitosis

(Hawkins. 2008).

Teknik yang digunakan pembuaan nanopartikel ini adalah teknik desolvasi. Prinsip dari teknik desolvasi ini adalah berdasarkan perubahan kelarutan BSA dalam air dengan penambahan pelarut pendesolvasi. Kelarutan BSA dalam air tinggi, bila ditambahkan desolvating agent/pelarut pendesolvasi (etanol, aseton, dan DMSO) akibatnya akan membentuk agregrat dari BSA, lalu ditambahkan glutaradehid sebagai cross-linker.

\section{METODE PENELITIAN}

\section{Bahan dan Alat}

Bahan-bahan yang digunakan adalah Bovine Serum Albumin atau BSA (Sigma Aldrich), $\mathrm{NaOH}$, Etanol, Aseton, DMSO, Glutaraldehid (Merck).

Alat-alat yang digunakan adalah Neraca Analitik (Mettler Toledo ${ }^{\circledR}$ XS205), pengaduk magnetic stirrer, sonikator tipe bath (Krisbow ultrasonic Cleaner), alat analisis ukuran partikel dan zeta potensial $\left(\right.$ Delsa $^{\mathrm{TM}}$ Nano C Particle Analyzer, Beckman Coulter), $\mathrm{pH}$ meter (Mettler Toledo ${ }^{\circledR}$ S20), Scanning Electron Microscope, alat mikrosentrifuga (Hsiang Tai), tabung mikrosentrifuga, kuvet disposable, dan alat gelas lain yang umum digunakan di laboratorium.

\section{Pembuatan Nanopartikel BSA}

Pembuatan Nanopartikel pada penelitian ini menggunakan sistem bottom up dengan teknik desolvasi. Pada tahap awal dilakukan pembuatan nanopartikel yaitu dengan melarutkan BSA pada aquadest, diatur agar $\mathrm{pH}$ menjadi $\mathrm{pH}$ 9, Kemudian ditambahkan desolvating agent, dan glutaraldehid sebagai crosslink. Optimasi dilakukan pada jenis desolvating agent, jumlah pelarut pendesolvasi, jumlah BSA, jumlah desolvating agent, lama waktu pengadukan, dan $\mathrm{pH}$ pelarut.

\section{Karakterisasi Nanopartikel}

Karakterisasi fisika nanopartikel meliputi ukuran partikel dengan alat PSA. Morfologi ukuran partikel dengan menggunakan alat SEM yang dapat melihat permukaan dan bentuk dari nanopartikel yang terbentuk. Indeks polidispersitas, dan zeta potensial ditentukan dengan alat PSA.

\section{HASIL DAN PEMBAHASAN}

Berbagai parameter yang dioptimasi pada penelitian ini dilakukan pada jenis desolvating agent, jumlah pelarut pendesolvasi, jumlah BSA, jumlah desolvating agent, lama waktu pengadukan, dan $\mathrm{pH}$ pelarut. 
Tabel 1. Pengaruh Jenis Pelarut pada Ukuran Partikel dan Indeks Polidispersitasnya Nanopartikel BSA

\begin{tabular}{ccc}
\hline Jenis Pelarut & Ukuran Partikel (nm) & Indeks Polidispersitas \\
Pendesolvasi & & \\
\hline Etanol & $94,1 \pm 7,85$ & $0,294 \pm 0,062$ \\
Aseton & $114,27 \pm 11,24$ & $0,269 \pm 0,118$ \\
DMSO & $*$ & $*$ \\
\hline
\end{tabular}

*tidak terbentuk Nanopartikel

Jenis pelarut pendesolvasi yang dioptimasi menggunakan etanol, aseton, dan DMSO. Penggunaan etanol, aseton, sebagai pelarut pendesolvasi membentuk nanopartikel dengan ukuran masingmasing $94,1 \pm 7,85 ; 114,27 \pm 11,24 \mathrm{~nm}$. Etanol membentuk ukuran nano yang lebih kecil dari pada aseton sedangkan pada DMSO tidak terbentuk kekeruhan yang menandakan tidak terbentuknya nanopartikel. Hal ini disebabkan karena perbedaan kepolaran dari jenis pelarut pendesolvasi. Konstanta dielektrik dari aseton, etanol, dan DMSO secara berturutturut adalah 21; 24,5; dan 47. Konstanta dielektrik dari DMSO yang paling tinggi, menandakan bahwa DMSO pelarut yang polar, sehingga tidak dapat mengubah kelarutan BSA dalam air. Dipilih Aseton sebagi pelarut pendesolvasi karena morfologi dari nanopartikel yang menggunakan aseton bentuknya sferis. (Jenita, et al., 2012) bentuk nanopartikel yang kurang sferis akan mempermudah kontak antar partikel menjadi berujung pada agregasi.

Tabel 2. Pengaruh Jumlah BSA pada Ukuran Partikel dan Indeks Polidispersitas Nanopartikel BSA

\begin{tabular}{ccc}
\hline Jumlah BSA (mg)/2mL & Ukuran Partikel (nm) & Indeks Polidispersitas \\
\hline $\mathbf{2 0}$ & $89,13 \pm 8,087$ & $0,164 \pm 0,006$ \\
$\mathbf{3 0}$ & $114,27 \pm 11,24$ & $0,269 \pm 0,118$ \\
$\mathbf{5 0}$ & $349,50 \pm 34,43$ & $0,296 \pm 0,080$ \\
\hline
\end{tabular}

Konsentrasi BSA yang digunakan mempengaruhi ukuran nanopartikel (Tabel 2). Pada penelitian ini jumlah BSA divariasikan: 20; 30; dan $50 \mathrm{mg}$. Peningkatan jumlah BSA yang digunakan menghasilkan nanopartikel yang besar. Hal ini karena interaksi hidrofobik molekul protein semakin besar dengan meningkatnya konsentrasi atau jumlah BSA (Yeon J.dkk. 2011).

Tabel 3. Pengaruh Jumlah desolvating agent terhadap Ukuran dan Indeks Polidispersitas Nanopartikel BSA

\begin{tabular}{ccc}
\hline $\begin{array}{c}\text { Jumlah Desolvating agent } \\
(\mathbf{m L})\end{array}$ & Ukuran Partikel (nm) & Indeks Polidispersitas \\
\hline $\mathbf{2}$ & $*$ & $*$ \\
$\mathbf{4}$ & $114,27 \pm 11,24$ & $0,269 \pm 0,118$ \\
$\mathbf{8}$ & $* *$ & $* *$ \\
\hline *tidak terbentuk Nanopartikel & &
\end{tabular}

*tidak terbentuk Nanopartikel

**Agregasi

Prinsip metode Desolvasi adalah perubahan kelarutan BSA dalam sistem pelarut jika ditambahkan pelarut yang kurang polar, ditandai dengan timbulnya 
kekeruhan. Titik akhir terjadi kekeruhan sulit ditentukan saat aseton ditambahkan. (Paik, S.Y.R.dkk. 2013). Oleh karena itu dilakukan optimasi jumlah aseton yang ditambahkan sebagaimana ditunjukkan pada Tabel 3. Pada volume $2 \mathrm{~mL}$, belum terjadi kekeruhan yang menandakan belum terbentuknya nanopartikel. Peningkatan volume menjadi $4 \mathrm{~mL}$, terbentuk nanopartikel ditandai dengan terbentuk kekeruhan. Penambahan selanjutnya sampai $8 \mathrm{~mL}$ menyebabkan agregasi yang mengendap.

Tabel 4. Pengaruh Lama Waktu Pengadukan terhadap Ukuran dan Indeks Polidispersitas Nanopartikel BSA

\begin{tabular}{ccc}
\hline $\begin{array}{c}\text { Lama Waktu } \\
\text { Pengadukan (Jam) }\end{array}$ & Ukuran Partikel (nm) & Indeks Polidispersitas \\
\hline 3 & $114,27 \pm 11,24$ & $0,269 \pm 0,118$ \\
18 & $148,03 \pm 5,108$ & $0,200 \pm 0,006$ \\
24 & $193,73 \pm 5,052$ & $0,290 \pm 0,011$ \\
\hline
\end{tabular}

Tabel 4 memperlihatkan bahwa ukuran partikel berbanding lurus dengan waktu pengadukan. Pemberian energi mekanik yang berlebihan menghasilkan energi bebas permukaan partikel yang besar yang menyebabkan penggabungan partikel-partikel. Hal ini lah yang menyebabkan ukuran nanopartikel semakin besar.

Tabel 5. Pengaruh $\mathrm{pH}$ terhadap Ukuran dan Indeks Polidispersitas Nanopartikel BSA

\begin{tabular}{ccc}
\hline $\mathbf{p H}$ & Ukuran Partikel (nm) & Indeks Polidispersitas \\
\hline $\mathbf{6}$ & $*$ & $*$ \\
$\mathbf{7}$ & $293,13 \pm 2,99$ & $-0,277 \pm 0,012$ \\
$\mathbf{9}$ & $114,27 \pm 11,42$ & $0,269 \pm 0,118$ \\
\hline
\end{tabular}

*Agregasi

Dari Tabel 5. Selain faktor di atas, $\mathrm{pH}$ juga mempengaruhi ukuran nanopartikel. $\mathrm{pH}$ diatur di $\mathrm{pH} 9$ untuk menjauh dari titik isoelektrik dari BSA (titik isoelektrik dari BSA adalah $\mathrm{pH}$ 4.7). Ukuran partikel yang dihasilkan akan besar jika $\mathrm{pH}$ berada dekat dengan nilai titik isoelektrik dari BSA (Paik et al., 2013). Pada pH 9 terjadi tolakan elektrostatik di dalam sistem nanopartikel yang menyebabkan tidak terjadi koagulasi pada molekul protein.sehingga ukuran yang dihasilkan berukuran lebih kecil (Yeon et al., 2011).

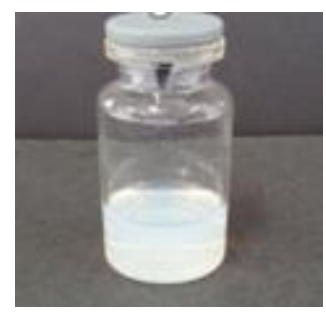

Gambar 2. Nanopartikel BSA dengan metode desolvasi 


\section{Scanning Electron Microscopy}

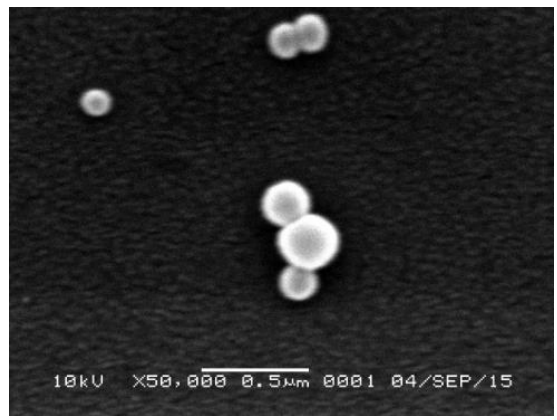

Gambar 3. Pengamatan SEM nanopartikel BSA perbesaran 50.000x

Fotomikrograf SEM di atas menunjukkan bahwa nanopartikel BSA memiliki bentuk morfologi berupa partikel sferis, walaupun terlihat kohesif karena sifat adesif dari BSA.

\section{SIMPULAN}

Berdasarkan data-data yang didapat pada penelitian ini, dapat disimpulkan bahwa nanopartikel BSA terbaik adalah nanopartikel BSA yang dibuat menggunakan $4 \mathrm{~mL}$ aseton sebagai desolvating agent dan $30 \mathrm{mg}$ BSA dalam $2 \mathrm{~mL}$ pelarut air, dengan lama waktu pengadukan selama 3 jam dan $\mathrm{pH} 9$.

\section{DAFTAR PUSTAKA}

Elzoghby, A.O., W.M. Samy, N A. Elgindy. 2011. Albumin-based nanoparticles as potential controlled release drug delivery systems. Journal of Controlled Release. 157(2): 168-182.

Hawkins, M.J., S.S. Patrick, N. Desai, N. 2008. Protein Nanoparticles as drug carrier in clinical medicine. Advanced Drug Delivery Reviews 60(8): 876-885.

Jenita, J.J,L., C.Vijaya, B. Wilson, B.K. Savitha, R. Suma. 2012. Design and characterization of bovine serum albumin nanocarriers for tenofovir by modified desolvation method. Journal of Pharmacy Research. 5(9): 4663-4667.

Ji Yeon, J., H.H. Nguyen, S.Y.R. Paik, H.S. Chun, B.C. Kang, S. Ko. 2011. Preparation of size-controlled bovine serum albumin (BSA) nanoparticles by modified desolvation method. Food Chemistry. 127(4): 1892-1898.

Paik, S.Y.R., H.H. Nguyen, J. Ryu, J.H. Che, T.S. Kang, J.K. Lee, C.W. Song, S. Ko. 2013. Robust size kontrol of bovine serum albumin (BSA) nanoparticles by intermittent addition of a desolvating agent and the particle formation mechanism. Food Chemistry. 141(2): 695-701.

Yuan, A., J. Wu, C. Song, X. Tang, Q. Qiao, L. Zhao, G. Gong, Y. Hu. 2013. A Novel self-assembly albumin nanocarrier for reducing doxorubicin-mediated cardiotoxicity. Journal of Pharmaceutical Sciences. 102(5): 1626-1635. 